\title{
日本臨床麻酔学会第24 回大会特別講演
}

\section{謎につつまれた華岡青洲の生涯 一麻沸散による全身麻酔施行 200 周年を記念して一}

松木明知*

[要旨] 華岡青洲 (1760 1835) は江戸時代後期の医師であるが, 1804 年に麻 沸散を用いて，世界で初めて全身麻酔を行ったことで広く知られている。しい青洲 自身記録や著書を書かなかったため, 多くのことが謎として未解決のまま残されてい る. 例えば彼の末娘の名前や生没年はまったくわからなかった.

著者は青洲と同じ麻沸散を作り, 動物実験を繰り返し, 麻沸散開発の経緯を明らか にした. また華岡家の菩提寺であった地蔵寺の過去帳を発見して，青洲のこれまで知 られていなかった兄弟, 子女の名前や没年を明らかにした. 青洲の思想「内外合一活 物窮理」は現代の医学においても通用する. キーワード：華岡青洲, 麻沸散, 全身麻酔

（日臨麻会誌 Vol.25 No.5, 427～440, 2005）

日本臨床麻酔学会第 24 回大会におきまして，特 別講演を行う機会を与えられましたが，私にとり まして大変名誉なことと存じます。大会長である 和歌山県立医科大学の畑埜教授のご配慮に心から 感謝を申し上げますとともに，司会の労をお取り いただいている東京大学の花岡教授にも厚くお礼 申し上げます。

さて本日は，華岡青洲について，私が過去約 40 年間研究してまいりましたことをお話申し上げま す．2004年は紀州の華岡青洲が世界で初めて全身麻 酔下の手術を敢行してから 200 周年になり，このこ とを考慮されて畑埜会長が私に青洲についての講演 を要請したものと存じます。

分子生物学，遺伝子治療など日進月歩どころか, 秒進分歩とでも表現しなければならないほど発達し
つづけているこの現代に，何をいまさら 200 年前の 華岡青洲だという方がおられるかもしれません。こ のように思われる方は，次の言葉に耳を傾けてくだ さい.

日本の電気生理学のパイオニアである東京帝国大 学の橋田邦彦は今から 70 年ほど前にこのように述 べております。

橋を渡るのに

一尺の幅しか要らないが,

一尺の幅しかない橋は

渡れるものでない。

現代は，研究者や臨床家の関心が，あまりにも他 人と競って先を急ぐことのみに集中しているため, 
自分がどこを歩んでいるのか，どこを目標に歩めば よいのか，そのためどのように歩めばよいのかを知 りません。そして自分の歩いている道が非常に狭い ことも知りません。「一尺の幅しかない橋」とはこ のことです．専門化が急速に進んでいる現在, 自分 の専門分野は非常に限定されております。「橋を渡 るのに，一尺の幅しか要らない」とはこのことなの です。しかし臨床家にとりましては「一尺の幅の橋」 を渡るのは危険です。このような危険な橋を考える こともせずに渡ったのが, 東京慈恵会医科大学青戸 病院の泌尿器科の医者たちです.

本日の私の講演を聞いたとしても，直接的に目の 前の患者の命が助かるわけではありません。しかし 皆さんが渡っている橋の幅をいささか広げる役目を 果たすのではないかと考えております. 加えて, 皆 さんのなかの然るべき人が, 外国の方から日本の麻 酔科学の先駆者としての華岡青洲について尋ねられ て, 何も返答ができないならば，もはやその方は相 手にされないでしょう。

さて, 私の講演の内容は次の通りです.

1 なぜいま華岡青洲なのか

2 青洲の家系はすべて明らかか

3 麻沸散はいつ完成したのか

4 最初の全身麻酔はいつ行われたのか

5 「乳嚴治験録」は青洲の自筆か

6 乳癌手術患者は術後どれくらい生存したのか

7 青洲の業績から何を学ぶか

まず第一の「なぜいま華岡青洲なのか」について 申し上げます。ご承知のように現在は，目まぐるし い変革の時代です．急速に変化しておりますから, 先が見えません。このような時代であるからこそ， 目標が必要であります。暗黒の嵐の中で, 船は進む ことはできません.このようなとき, 灯台の光があ れば安心です。現代では灯台の光でなく，GPSだと いうかもしれません。私は医療人として, 医学, 哲 学, 宗教, 芸術, 経済の 5 科目の研修が不可欠と長 年主張してまいりましたが, 青洲は医学, 哲学, 宗
教，芸術，経済のいずれの点からみましても第一級 の人物であり，だからこそ 200 年という歳月を超え て，わ独机の目標たりうる人物と考えております。 このことが「なぜいま青洲なのか」の第一の理由で す。現在はまた混乱の時代で, 医療人としていかに あるべきかが，強く問われております。社会がわれ われ医療人に強く求女ているのは，高い人間性であ ります。先ほど申し上げました東京慈恵会医大青戸 病院の泌尿器科の医師たちにとって, 最も欠如して いたのがこの人間性の陶治です。青洲はこのことを 最も重視しました。これが第二の理由です。以上述

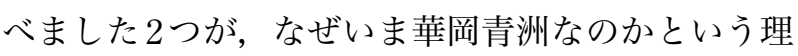
由です。

次に，華岡青洲の略歴についてお話し申しあげま す。青洲は 1760 年(宝暦 10 年)に紀州名手村字平山 の村医華岡直道の長男として生まれました。名手村 は現在の和歌山県那賀郡那賀町になります。1782年 (天明 2 年), 当時の日本の医学のメッカの一つであ つた京都に遊学し, 吉益南涯, 大和見立らに師事し ました。 3 年後の 1785 年(天明 5 年) 2 月，青洲は京都 から帰郷しましたが，その6月に父直道は没しまし た. 青洲は一家を支えるため一生懸命働きましたが, 同時に研究も行ったようであります。そして1796年 (寛政8年)頃, 経口的全身麻酔薬「麻沸散」がほぼ 完成の域に近づきました。それから 8 年後の 1804 年 (文化元年) 10 月に最初の全身麻酔下の乳癌手術が行 われました。翌 1805 年(文化 2 年) 9 月には，機を織 つて青洲の京都遊学の仕送りを続けた妹の小陸(こ むつ)が死亡しました。青洲が69歳の 1829 年(文政 12 年)に妻の加恵が没しました。その 6 年後の 1835 年 (天保6年)青洲は 75歳で亡くなりました。1919年 (大正 8 年) 生前の功により正五位が追贈され，1960 年 (昭和 35 年) に和歌山市で生誕 200 年祭が盛大に挙 行されました。したがいまして，青洲は 18 世紀後 半から 19 世紀前半にかけての人物であります.

青洲をより理解するため, 日本と世界の時代背景 についてお話します。日本では 1754 年(宝暦 4 年)山 
脇東洋が京都で死体解剖を行い，それから 17 年経 つた 1771 年(明和 8 年) 江戸の杉田玄白らは，クルム スの解剖書のオランダ語訳を携えて腑分けを見学し ました。玄白らは 3 年後にこのクルムスのオランダ 語訳の解剖書を漢文に翻訳しました。1776年(安永 5 年)には平賀源内がエレキテルを完成し，1803年(享 和 3 年)には大阪の伏屋素狄が動物実験を行って腎 臓の濾過作用を発見しました。1823年(文政6年)に ドイツ人のシーボルトが出島にあった蘭館の医師と して来日しました。つまり青洲が活躍した時代は, 日本では実証主義の医学が発達した時代でありま す。つまり単に言い伝えられてきたことを盲信する のではなく，一つ一つ自分の目で確認するという考 えが普及し始めた時代でした。

目を世界に向けますと, 1766 年(明和 3 年)には才 ーストリアのメスメルが催眠術を提唱し，1771年 (明和 8 年)に英国のプリーストリーが酸素を発見し ました。1794年(寛政6年)英国のベドウズはクリフ トンに気体研究所を設立し, 弱冠 20 歳で所長に抜 擢されたデービーは 1800 年(寛政 12 年)に亜酸化窒 素(笑気)の鎮痛作用を見出しました。1803年(享和3 年)ドイツのゼルトナーはモルヒネの分離に成功し, 1818年(文政元年) 英国のファラデーはエーテルの鎮 痛作用を指摘しました。そして1846年(弘化 3 年)ア メリカのモートンによってエーテル麻酔の公開実験 が行われ，成功裏に終わりました。つまり青洲の時 代, 欧米では気体の化学的, 臨床への応用的研究が 始まったといってよいと思います。

これで当時の時代背景がご理解いただけたと思い ます。

華岡青洲は在世当時から有名でしたが, 東京帝国 大学の精神科の教授で, 医学史の研究者としても知 られている呉秀三が 1923 年 (大正 12 年)に大著「華 岡青洲先生及其外科」を著しました. 呉が東京帝大 教授であることに加えて，あまりにも著名な医学史 の研究者であったため, その後青洲について本格的 に研究する研究者が現われず，以来約 80 年間日本
の医学史研究者はいずれも呉の説に盲従してきまし た。それでも青洲の名は医学関係者の間でしか知ら れておりませんでした。青洲の名前が一般の人々の 間にも広く知られるようになったのは，なんといつ ても和歌山県出身の作家，有吉佐和子が1967年(昭 和 42 年)に「華岡青洲の妻」を発表してからです. この作品は脚本化され，芸術座，新橋演舞場などで 1,000 回近く上演されたことも, 青洲の名が人々の 間に浸透した大きな理由でありましょう。しかし有 吉はこの作品のなかで「乳嚴治験録」の一部や青洲 宛の杉田玄白の書簡の原文を引用しているため, 多 くの読者はこの作品をフイクションと思わず，歴と したノンフィクションであると䛊解したようです。 有吉もすべての材料を呉の著書に準拠しているた め，肝心な箇所に重大な誤りがあります，例えばこ の小説のクライマックスの一つに，機を織つて京都 に遊学中の青洲に仕送りを続けた妹の小陸が 1805年 (文化 2 年) 9 月，最初の全身麻酔下の手術が行われ た 1 カ月前に，兄青洲の大成功を見ずに死亡したと して読者の涙を誘いますが，実際は手術が前年の 1804 年(文化元年)に行われているため，小陸は兄の 大成功を目の当たりにして死んでいったのでありま す。小説は小説として別に目くじらを立てょうとは 思いませんが, 多くの読者, そして医学関係者まで もが，小説を小説と理解せず，事実と誤解してしま うところが問題なのです.

次に青洲の家系について申し上げます。青洲は研 究はもちろんのこと, 京都遊学などについて家族の 大きな協力を得たといわれております。このことを 考えますと，正確な家系を知ることが大切なことで あります。現在, 直系のご子孫の華岡青洲博士(第 八代随賢)が札幌にお住まいですが，それでも家系 について不明な点がありました。今問題にしており ます青洲は，三代目の随賢です。これには訳がある のです. 第六代随賢の貞次郎が第一次世界大戦前後, 事業に失敗し地元を離れました。 その際家屋を売却 しましたが，当然重要な史料も散逸しました。さら 


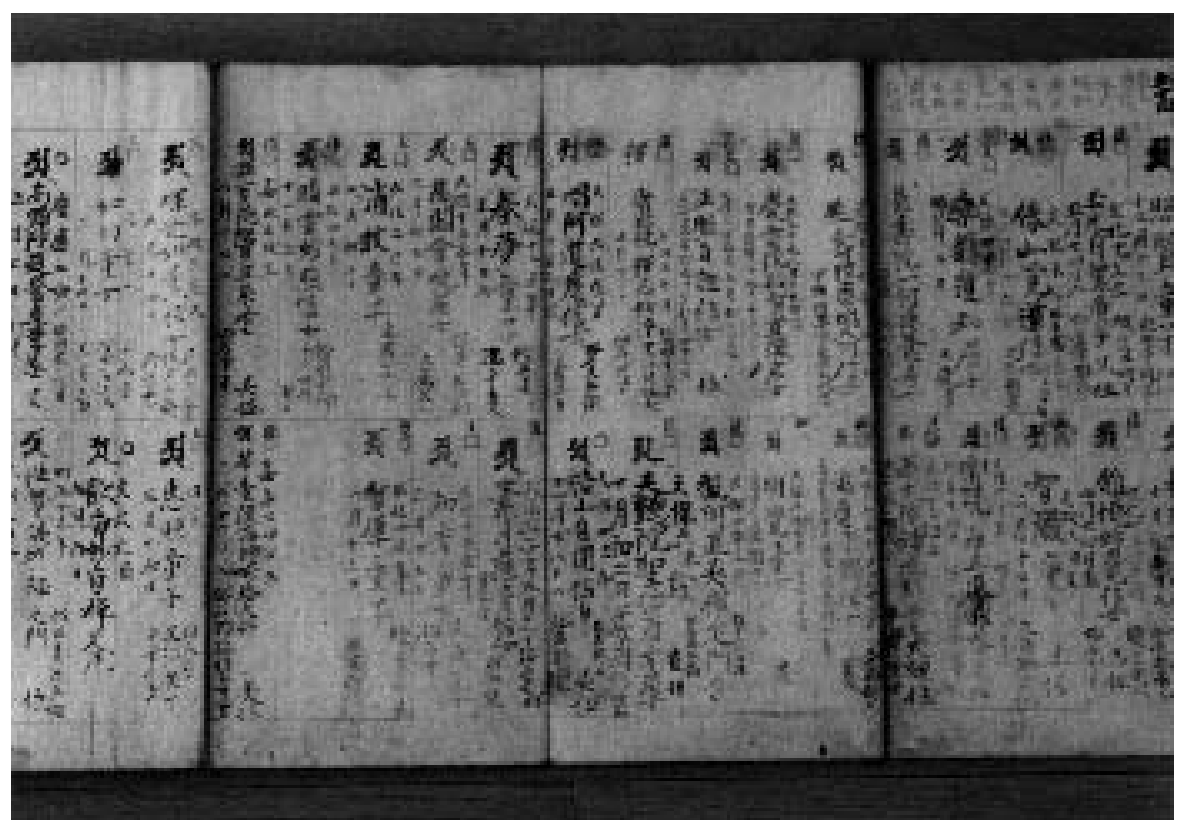

写真1 地蔵寺の過去帳の中で華岡青洲家の部分

に青洲在世当時の華岡家の菩提寺である真言宗の地 蔵寺が無住になってしまいました。つまり住職がい なくなったのであります。このため地蔵寺の過去帳 が行方不明になりました。私は数年かけてこの過去 帳を探し，遂に那賀町の西光寺に保存されているの を突き止めました(写真 1). 1997 年(平成 9 年)のこ とです。この過去帳には写真 1 に示すように華岡家 一族の百数十名の法名が記されており，これによっ て従来不明であった多くの人物の没年月日などが明 らかになりました．表 1 は青洲の弟妹を示したもの です。次女は従来「お陸」(こりく)と呼ばれてきま したが，過去帳には「小ムツ」とありますので「こ むつ」が正しい呼び方だと思います，三女は「たね」 と名前だけがこれまで知られていましたが，「於種」 と書き 1833 年(天保 4 年)に亡くなっております。四 女は名前も生没年も知られておらず，「黒江柳川家 に嫁す」とのみありますが，柳川家には嫁していま せん。過去帳から推察しますと, この人は 1816 年 (文化 13 年)に没している「キサ」ではないかと考 えられます。没年から推定いたしますと,「キサ」 が三女で，「於種」が四女と思われます。
次に青洲の子供たちです。妻の加恵との間に 7 人 の子供がおり, 長女, 長男, 次女, 次男, 三男, 三 女，四女の順序とされてきました。三女，四女は名 前すら不明でした。しかし過去帳の研究によって系 図が大きく変わりました。まず三女は「於栄」で 1806 年(文化 3 年)生まれです。したがって「於栄」 は次女「かめ」のすぐ下の妹で，次男「修平」のす ぐ上の姉になります。一番末の子供は四女で, 青洲 の次弟「治兵衛」の養女になったことだけがわかっ ていました。この過去帳に法名は見出されません. 私の 20 年にわたる探索の結果，この人の名前は 「たね」で 1902 年(明治 35 年)に満 80 歳で亡くなって います。そうしますと，「たね」は 1822 年(文政5年) に生まれたことになります。1822年(文政5年)には 青洲が 62 歳, 妻の加恵が 60 歳になります。1804年 (文化元年)すでに盲目になっていたはずの加恵の年 齢などを考慮すれば，この四女の「たね」は青洲と 加恵との間にできた子供ではなくて，青洲がほかの 女に生ませた娘と考えられます。だからこそ青洲は 子供のいなかった次弟の治兵衛に養女として養育さ せたのでありましょう。華岡家は詳細な家系が公開 


\section{表 1 青洲の同胞と子女}

$\square$ は著書による新知見追加

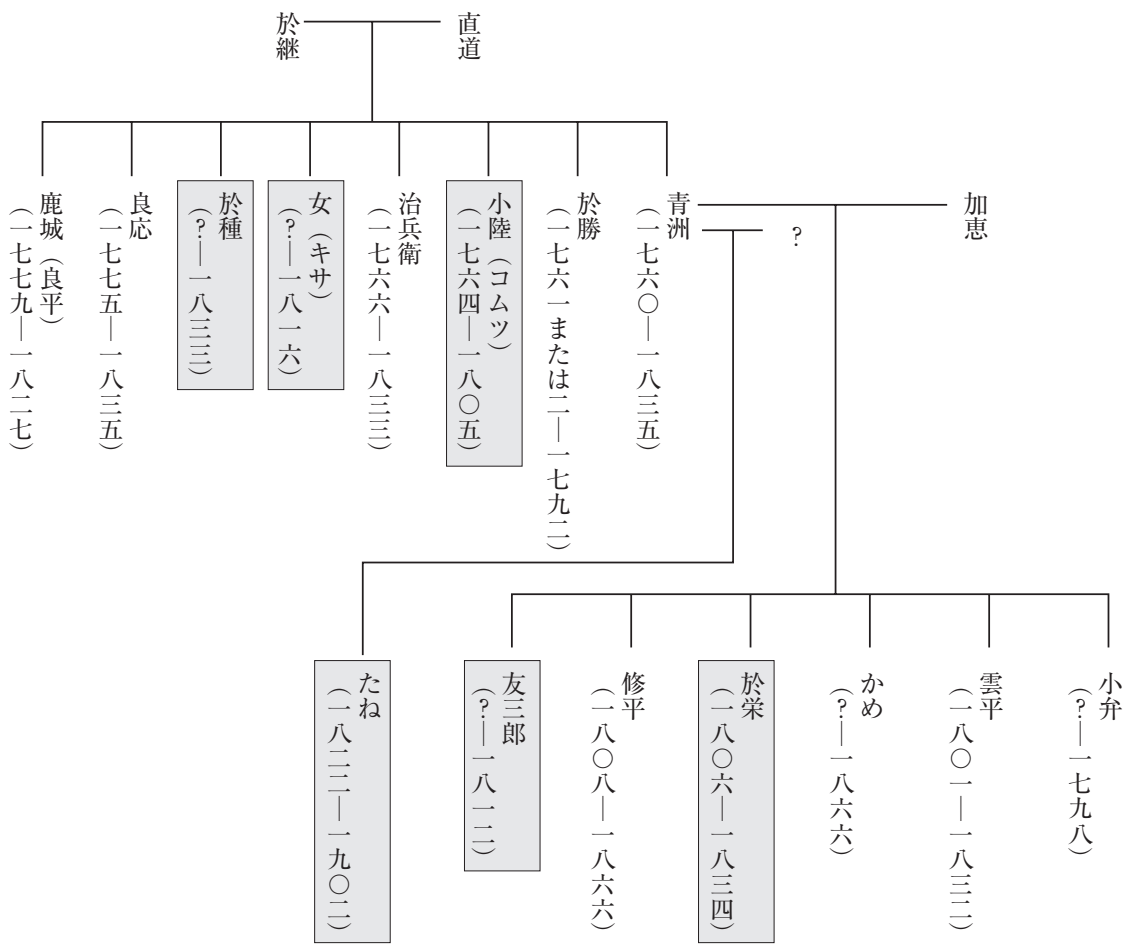

されている医家の一つですが，その華岡家で青洲の 兄弟姉妹, 子供に名前や生没年が不明な人がつい数 年前までいたとは驚くべきことです。

わからないのは青洲の同胞や子供たちばかりでは ありません. 妻の加恵の家系についても不明な点が 多いのです。加恵は紀州上那賀郡名手市場村の妹背 佐次兵衛の娘でしたが, 何代目の佐次兵衛の娘か不 明でした。妹背家のご子孫が現在どこに居住されて いるかわからず，また菩提寺である那賀町の安養寺 は以前の火災でいっさいの過去帳を失っており，こ の点から調査をすることは不可能です。那賀町名手 市場の俗に城山と呼ばれる地区は県道 127 号線で分 断されましたが, その東側に妹背佐次兵衛家の墓域 があります。写真2に示しましたように，17基の墓 碑と一つの小灯䉕が建立されています。この墓碑群 をこれまで誰も調査しておりませんでした。墓碑に 刻まれた戒名や那賀町の史料なども参考に考えます
と，1706年(宝永 3 年)に没した「明白重翁居士」が 初代，1730年(享保 15年)に没した「霍山道樹居士」 が第二代の佐次兵衛であろうと思います。このほか 没年が特定できますのは 1849 年(嘉永 2 年)に死亡し た「普明院俊哲重義居士」であります。この両者の 没年の差は 119 年であります。津軽藩の医師の家系 から約 200 名を対象として算出しますと, 当時一世 代は約 30 年でありましたから，「明白重翁居士」を 初代とすると,「普明院俊哲重義居士」は第六代に なり，第三代は 1760 年頃，第四代は 1790 年頃，第 五代は 1820 年頃に没したことが推定されます。青洲 の妻の加恵は 1762 年(宝暦 12 年)生まれですから, 第三代佐次兵衛の娘の可能性は低く, むしろ第四代 の佐次兵衛の娘である可能性が高いと推定されまし た。その後，たまたま札幌にお住まいの第八代の随 賢であります華岡青洲博士と連絡を取っておりまし たところ，同家の過去帳のなかに「真恕啓中居士 


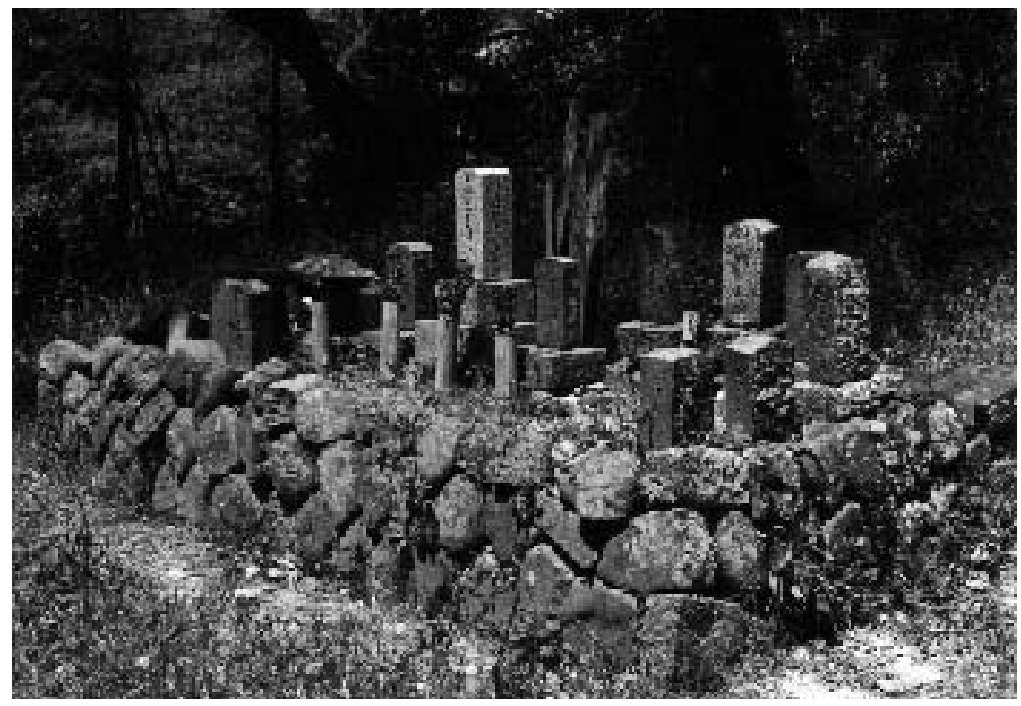

写真2 青洲の妻加恵の実家妹背家の墓碑

天明六午年二月十七日 妹背佐次兵衛敦英 加恵之 父」とあるのをご教示いただきました.

「天明六年」は 1786 年になり，私が推定した 1790 年とわずか 4 年しか違っておりません。このことに よって青洲の妻加恵は妹背家の第四代佐次兵衛の娘 であると考えて間違いがないと思われます。これま で述べてきましたように，家系の問題一つをとつて も，いかに多くのことがこれまで未解決のまま残さ れていたかがおわかりいただけたと思います。この 講演のタイトルを「謎につつまれた華岡青洲の生涯」 とした理由もおわかりいただけたと思います。

次に「麻沸散」がいつ完成したかについて申し上 げます。「麻沸散」についても大きな䛊解がありま す。この「麻沸散」は元来, 中国の三国時代の華佗 が用いた麻酔薬でした。しかしこの華佗の「麻沸散」 の処方内容はまったく知られておりません。「麻」 という字から推定して「大麻」が主成分であるとし たり，「蔓佗羅華」を主成分とする説がありますが, いずれも䛊りと考えられ，正確なことはわかってお りません.

青洲は華伦に強い憧れを抱いておりましたので, 完成した薬に華佗の用いたという「麻沸散」の名前 を借りてつけたのであります。別に「麻沸湯」,「通
仙散」ともいいます。

「麻沸散」の開発について記した「麻薬考」とい う史料があります。現在 4 種類の写本の存在が明ら かですが，そのなかの一冊は私の手元にあります. 写真 3 は最も状態のよい京都大学富士川文庫本で す。この本の著者は青洲の友人で弟子ともいわれる 中川修亭であります。

1796 年(寛政 8 年)に書かれた修亭の序文によりま すと,この頃までに修亭は麻沸散による全身麻酔を 10 数例目撃しているのです。いずれも「麻沸散」は 有効であったと記されております。前にも申し上げ ましたとおり，青洲が京都遊学から帰ったのは 1785 年 (天明 5 年) 2 月ですから，1796 年(寛政 8 年)まで に 11 年かかっています。しかし慎重であった青洲 はただちに臨床に応用することをしませんでした。 決して功を求めて先を急ぎませんでした。後で申し 上げますように，最初の全身麻酔は1804年(文化元 年)に行われておりますから，完璧を期すため 1796 年(寛政 8 年)からさらに 8 年の歳月を費やしたと思 われます。ここにこそ決して功をあせらなかった青 洲の偉大さがあると思われます。

京都遊学中，青洲は医療における鎮痛の重要性を 認識し，鎮痛についての文献の探索を熱心に行いま 


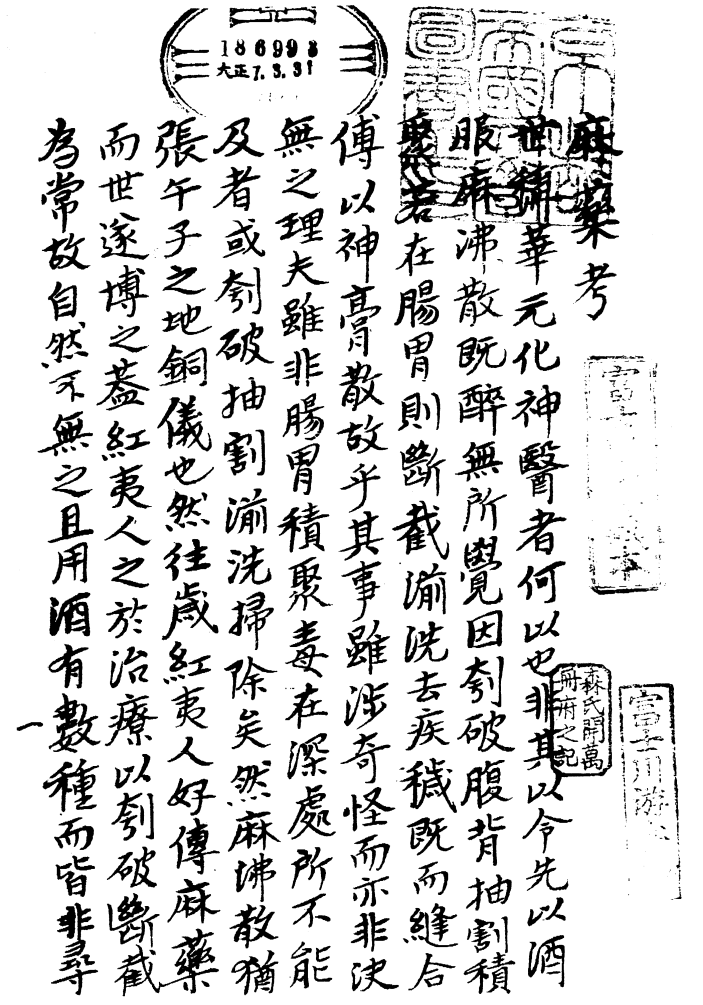

写真3 中川修亭の「麻薬考」(京都大学富士川文庫) 第1枚目「表」

した。そして遂に先人の花井仙蔵, 大西晴信らが 種々の麻酔薬を用いていることを知りました。この ことは中川修亭の「麻薬考」に記されております。 青洲は京都での修業中に，すでにそれらの情報を入 手していたと考えられますが，故郷に帰ってから動 物実験を含めた研究を本格的に始めたようです。し かし，どのような動物をどれくらい用いたのかなど の詳しいことはまったく知られていません.

私も青洲と同じ処方で「麻沸散」を作りました。 この「麻沸散」をイヌ, ウサギ，ラット，マウスに 投与して，実験を繰り返しましたが，ヒトの投与量 に比較して，2倍，3倍，5倍，10倍量を与えてもこ れらの動物では麻酔の状態を作り出すことはできま せんでした。一方，少し状態の悪いイヌに 3 倍量を 投与したところ，このイ邓は急死しました。ささに 私は教室の馬場先生に麻沸散を飲んでもらいまし
た. 服用後約 1 時間で意識は朦朧とした状態となり ました。この後麻酔効果は 8 時間続きました。瞳孔 の散大は約 1 週間続きました。

このような私の動物実験の結果などを考慮いたし ますと，たとえ青洲がいくら動物実験を繰り返した としても，ヒトに対する麻沸散の至適投与量を決定 することはできなかったと推察されます。だからこ そ青洲は母の於継や妻の加恵に被験者として協力し てもらい，長期間をかけて麻沸散の量を少しずつ増 やし, 最終的にヒトに対する至適な処方, 至適投与 量を決定したのだと考えられます。このことも伝聞 だけで，正確な記録は何も残されておりません，従 来の研究では, なぜ青洲が麻沸散の開発に 20 年近 くの歳月を費やしたのかわかりませんでしたが，私 が動物実験を繰り返した結果，その理由を明解に説 明できたのではないかと思います。私はこのような 研究を実験医史学と呼んでおります。

青洲が「麻沸散」の開発に思いを寄せた影には, 次のようなエピソードがあります。京都で修業中, 青洲は永富独嘯庵の「漫遊雑記」を読む機会があり ました。そのなかに「乳岩は治せず。古より然り。 而れども，和蘭の書中に言わるることあり。曰く. その初発梅核のごとくなる時, 快刀を以て之を割き, 金創之法に従って, 之を治す。この言味わい有り。 余と雖も，未だ之を試さず。書して以て後の人に告 ぐ.」とあり，この文章を読んで青洲は発奮したの です。永富独嘯庵が見たオランダの外科書, そして 恐らく青洲も見たと思われる本は，オランダ語の八 イステルの外科書でありましょう。1768年の英語版 にある乳癌手術の模様を見ますと，大変残酷な手術 方法であることがわかります。乳房の底部に長い針 を十文字に刺し，太い糸をかけて持ち上げ，刀のよ うなメスで乳房を切断します。当然出血しますが, それに対しては焼き鏝で焼いて止血します。これで は痛みのため気を失うのが当然でしょう。麻酔なし で乳房を切断するのですから，患者は大抵失神した と思われます，物の本に拠りますと，大の大人でも 
足首に五寸釘を刺されますと, 痛みに耐えかねて失 神するそうであります。このような状況では，とて も手術などはできないと青洲は悩み，鎮痛法つまり 全身麻酔の開発こそ，医療に不可欠と考えて，それ に全力を傾注したと思われます。

このようにして青洲は「麻沸散」の完成にこぎつ けましたが，それはおよそ1804年(文化元年)の少し 前であったと考えられます。「乳嚴姓名録」に 1804 年から患者の名前が記されているからです。この年 の正月， 2 月， 6 月に 3 人の患者が青洲の許を訪れて おりますが，いずれの患者も恐ろしさに手術を拒否 しました。そうしているうちに第 4 番目の患者が現 われました。この患者は大和国五條駅(現在の奈良 県五條市) 藍屋利兵衛の母かえ 60 歳でした。この症 例については詳細な記録が「乳嚴治験録」として残 つています。この記録では手術の日が年紀を欠くも のの，「十月十三日」となっております。ところが 乳癌患者の名前を記した「乳嚴姓名録」には，藍屋 利兵衛の母の上に「文化元年十月既望」とあります. 「既望」とは 16 日のことです。2つの史料の間に 「13日」と「16日」と 3 日の違いがあるのです。こ の差異があるため, 従来次のように解釈されてきま した。藍屋かんが初めて青洲の許を訪れ, 診療を求 めたのが1804年(文化元年) 10 月 16 日でありました. しかし, かんの一般状態が悪かったので, その改善 に約 1 年を要し，ようやく翌 1805 年(文化 2 年)の 10 月13日に手術が行われたというのでありました。

私は呉先生のこの解釈に大きな疑問を感じまし た。いくら昔でも癌患者の状態改善に 1 年間も要す るでありましょうか. 常識的にはそんなにかからな いはずです。先輩の研究者たちのいずれも呉秀三先 生の説に圧倒されて, このことに気がつきませんで した，何故気がつかなかったと申しますと, 実は彼 らが原史料である「乳倣治験録」を丁寧に読んでい なかったのです。「乳嚴治験録」によりますと，患 者の藍屋かんの初診時, かえは脚気を患っていまし た。このため青洲は脚気を治してから手術を行うこ
とにしましたが, 脚気の治療に約 20 日かかりまし た。これで手術をしてもらえると思ったがは，再 び青洲を訪ねますが，かえは今度は喘息気味でした。 このためがは診療所である春林軒に約 20 日程入院 しました。これでからの体調はすっかり整い，手術 が行われました。そういたしますと，初診から約 40 日でかえの手術が行われたことになります。この 「乳嚴治験録」の記述から 1 年後に行われたという のは間違いであると断言できます。しかし慎重を期 してこのことをほかの方法で証明しなければなりま せん。唯一残された手懸りは，かえがいつ死亡した かであります。ある程度進行した癌の状態でかえは 手術を受けたわけですから，そんなに長生きしてい ないでしょう。したがって，かえの没年月日から手 術日を特定できるかもしれないというのが，私の推 理でした。交方は大和五條駅の出身ですから，現在 の五條市の寺院を数年かけて調査しました.

幸いにも五條市教育委員会などのご協力もあって 講御堂寺の過去帳「引導霊簿」の文化二年度 $(1805$ 年)の条にがのの法名を見出すことができました。 次のように記されています(写真4).

春月智了信女 二月二十六日 北之町 藍屋利兵衛 母

過去帳の記述は，政治的，経済的意図などありま せんので，信頼できるものと思います。したがいま して，(1)青洲が乳癌の治療を開始したのは「乳孷 (岩)姓名録」によれば1804年(文化元年) 1 月以降, (2)「乳嚴治験録」によれば手術日は10月13日，(3) 「乳嚴姓名録」によれば手術日は10月16日，(4)かん は 1805 年(文化 2 年) 2 月 26 日に死亡という 4 条件か らかえの手術日は 1804 年(文化元年) 10 月 13 日と特 定できました。ただ，ここで問題になるのは，「乳 嚴治験録」の「13日」と「乳嚴姓名録」の「16日」 の間の 3 日の違いです。この違いはよくわかりませ んが，私は次のように解釈しております。この症例 


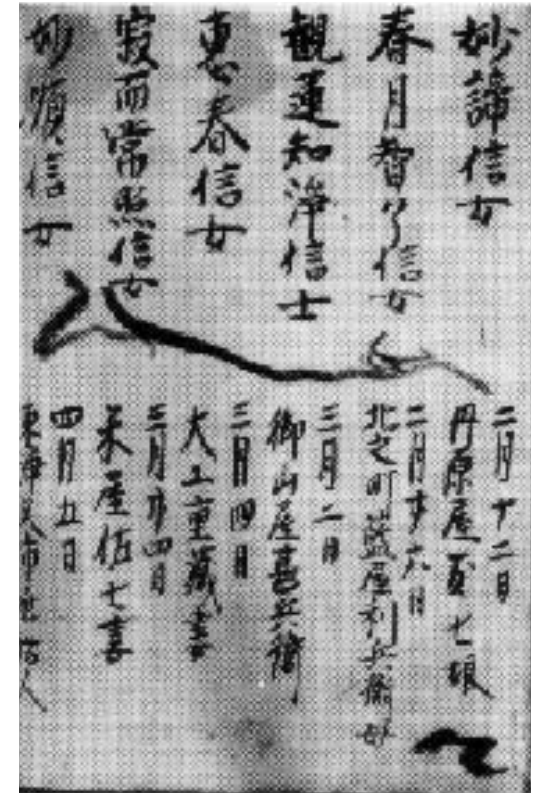

写真4 奈良県五條市講御堂寺の過 去帳（文化2 年の条）

右から二番目の「春月智了信 女」が藍屋かんの法名 (2月 26日没）

について詳しく記している「乳嚴治験録」にあるよ うに，手術は10月13日に行われました。「麻沸散」 を用いた最初の症例であるため, 青洲らは術後管理 に全精神を集中しなければなりませんでした。その ためかえの状態が落ち着いた 3 日後の「16日」にな って初めて手術台帳ともいうべき「乳嚴姓名録」に かえの名前を記入しました。このように解釈するの が，最も妥当ではないかと思われます。

この麻沸散による全身麻酔下の手術は華岡青洲の 最大の業績です。そして患者と術者の名前が知られ ていること, 病名と手術名がわかっていること, 手 術年月日が特定できること，詳細な記録が残されて いることなどによって，かえの症例は世界で最初の 全身麻酔であると評価されているのです。

「乳嚴治験録」は日本医学史上最も貴重な史料の 一つといわれております。現在は天理大学附属天理 図書館に所蔵されておりますが，先ほど申し上げま した「華岡青洲先生及其外科」を著した只秀三がか
つて所有していたものでした。もともとは華岡家に あったのでしょうが，いつの間にか持ち出されて, 呉秀三の手に入ったものと思われます。呉はこの 「乳嚴治験録」を用いてあの大著を執筆したのであ ります。呉はここで大きな䛊りを犯しましたが，只 が東京帝国大学精神科の教授で，かつあまりにも偉 大な医史学者であったため, 後続の研究者はいずれ も呉の説に盲従して，何も疑うことをしませんでし た. 呉によって, 青洲の生涯が多少伝説化されたこ とは否定できません.

呉の誤りの一つはか் 年)としたことです。「乳嚴治験録」には年紀がない のに，1805年(文化 2 年)と判断したことです。これ については，先ほど述べましたように，藍屋かん の没年月日を明らかにして，私は呉の誤りを指摘 し訂正いたしました。私の研究によって, 岩波書 店から出されている歴史学研究会編の日本史年表 も訂正されました。

呉はもう一つ大きな誤りを犯しました。それは 「乳嚴治験録」を青洲の自筆としたことであります。 そのことをこれから実証したいと思います。

「乳嚴治験録」を丁寧に読みますと, 漢詩を得意 とした青洲が自ら書いたとは思われない漢字の誤り があるのです。例えば医術を意味する「方技」を 「方枝」と書いております。当時医学を勉強した人 であれば，決して間違うことのない言葉であったと 思われます。また別の個所では，「乳岩」を「亂岩」 と記しています。それこそ乳癌の治療に生涯を捧げ たといっても過言ではない青洲が「乳岩」を「亂岩」 と書き間違うでしょうか。例えばいくら字が似てい るといっても, 皆さんは「内科」を「肉科」, そし て「麻酔科」を「床酔科」とは書かないでしょう。 これだけからも「乳巌治験録」が青洲自筆と考える

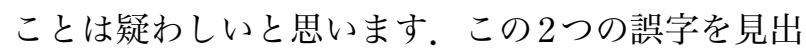
すことはきわめて容易なことで, 特別に高度な漢文 の知識を何も必要としません。このような䛊りが 80 年にもわたって看過されてきた陰には, 先ほども申 

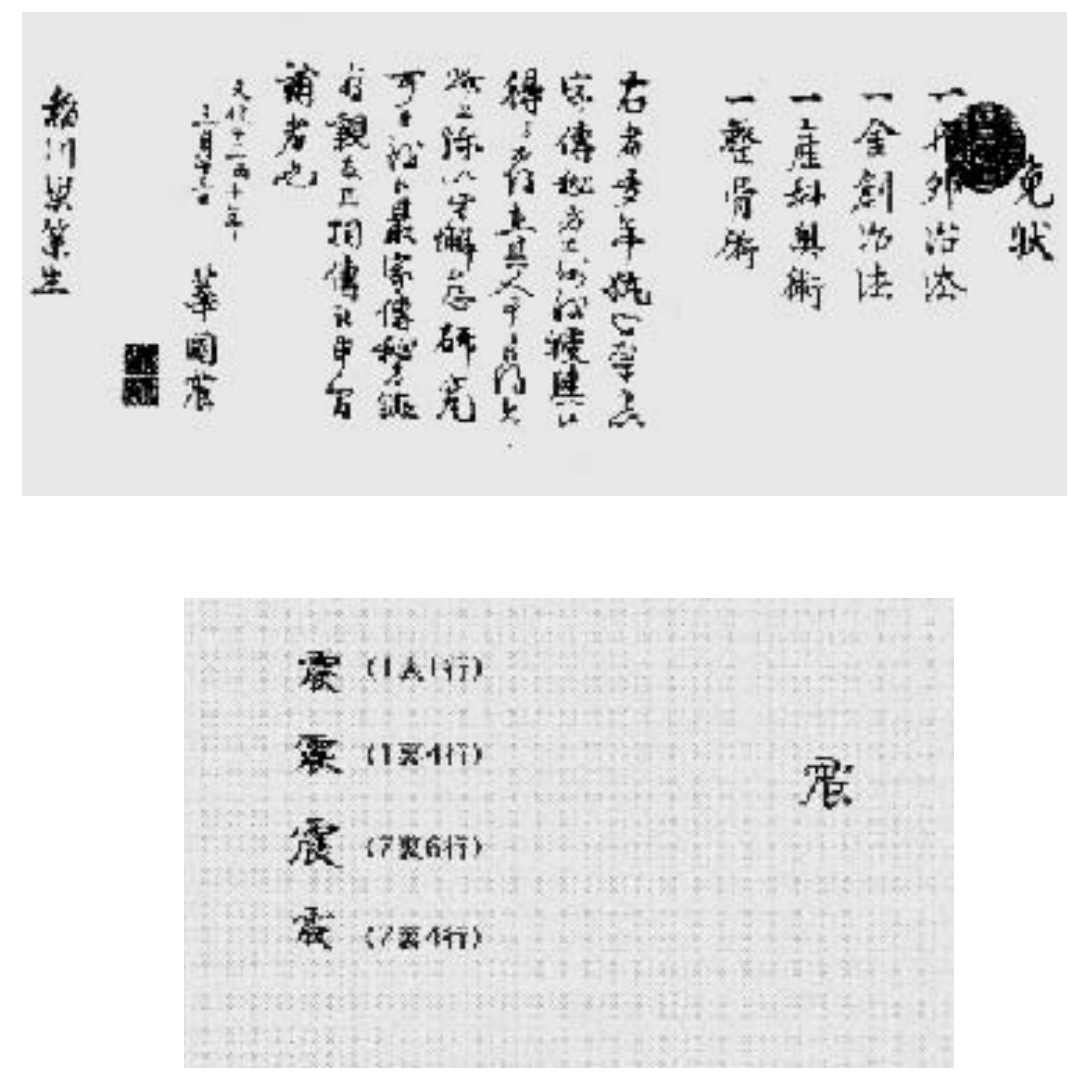

\section{写真 5 青洲自筆の免状と名前「震」の比較}

し上げましたように呉秀三があまりにも偉大な学者 であったため, 呉の説を盲信したことに加えて, 研 究者の誰もが原史料である「乳巌治験録」を実見し て正確に読んでいなかったことが指摘されます。原 史料を見ることの大切さ，オリジナルを読むことの 重要性を指摘しておきたいと思います。

さらに「乳嚴治験録」が青洲の自筆ではない証拠 を提示してみたいと思います。写真5の上は青洲が 弟子の稲川梁策に与えた免状です。間違いなく青洲 の自筆です。この免状の末尾に記された「華岡震」 の「震」と「乳嚴治験録」の末尾に書かれた「震」 を比較したのが写真 5 の下の写真です。成人であれ ば, 自分の名前の筆跡は年単位でみましても滅多に 変わるものでありません。「震」の終筆を見ると, 免状では短く点状になっているのに対して，「乳嚴 治験録」の「震」では終筆が右下に向かって長くな
っており，両者は明らかに異なります。同じように 三水のついた字と「術」を比較したのが写真6です。 いずれも左は「乳嚴治験録」, 右は免状の字です。 まず三水の字についてみますと, 免状では一本の線 のように下方に下りて，そこで跳ね上がります。し かし「乳嚴治験録」では三水の第二筆が横に大きく 長く書かれており，両者は明らかに異なります。 「術」の字についてみても，免状では「術」の「求」 に点がありますが,「乳嚴治験録」では点がありま せん。このほかにも多くの漢字で明らかな違いが認 められます。つまり誤字や筆跡の点から,「乳嚴治 験録」は決して青洲の自筆ではありえないと考えら れます。

では一体誰が書いたのかということになります が，これはきわめて難しい問題です。というのは青 洲を含めまして比較対照しなければならない人たち 
स经

斻(1要1行)

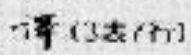

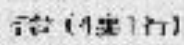

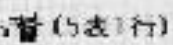

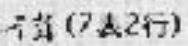

$-3 x(12 x)$
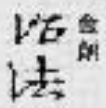

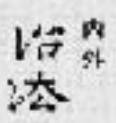

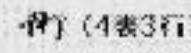

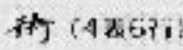

倷

ft] $\{12,2 \pi\}$

Ho $(5,4+4)$

Axis

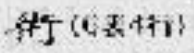

枿 (6x: in)

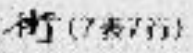

\section{写真6 三水の字と「術」の字の比較}

の自筆の史料がほとんどないからであります。しか しあえて申し上げますと, 私は青洲の一番下の弟で ある良平(鹿城)が青洲の口述などを聞いて書いたと 推定しており，その根拠もあるのですが，時間の関 係上ここではこれ以上申し上げません.

このようにして，青洲は多くの患者に対して全身 麻酔下に手術を行いましたが，とりわけ乳癌患者の 治療を熱心に行いました。青洲が「麻沸散」の開発 に取り組んだのも，もともと先ほど申し上げました ように永富独嘯庵の乳癌の記述を読んだからでし た. 青洲が治療した乳癌患者の名前と住所, そして 手術日を記した「乳嚴姓名録」が残されています。 これによりますと，1804年(文化元年)から 1848 年 (天保 6 年)までに治療した計 156 名の患者の名前が 記されております。最初に記されております 3 名は 手術を受けませんでした。また再発例が 6 名, 三発
例が 2 名おりますので，結局手術を受けた患者は計 143名ということになります。これら手術を受けた 患者が術後どれくらいの期間生存したかは, 従来ま ったく知られるところがありませんでした。

最初に手術を受けた藍屋がは, 術後約 4 力月半 で死亡しました。この症例も前述したように私が死 亡年月日を特定しました。「乳嚴姓名録」中の患者 の死亡年月日を特定することはきわめて困難を伴う 仕事であります。と申しますのは, 次の 4 つの理由 があるからです. (1)住所に誤りがある可能性があり, このため地域と菩提寺を特定できないこと，(2)菩提 寺が特定できても, 火災その他の理由で過去帳が失 われていること，(3)過去帳があっても，名前に誤り がある可能性があるため, その人物を見出せないこ と, (4)住所に誤りがなく, 菩提寺が特定でき, 過去 帳が残っていても，プライバシー問題のため閲覧は おろか, 何の情報も得られない場合があることです。 このような 4 つの理由のため,「乳嚴姓名録」に披 見される患者の死亡年月日を特定することはきわめ て困難な作業でした。私は過去三十数年にわたって この調査を続けてまいりましたが，ようやく 33 名 の患者の死亡年月日を明らかにすることができまし た。 1 年間に 1 人の割合になります。全体 143 名の $23 \%$ にあたります。

次に私が死亡年月日の特定に苦労した例を $2 つ ほ$ ど紹介したいと思います。「乳嚴姓名録」の第 79 番 には次のようにあります。「文化十四年六月念九 房州味形 光林寺 室」です。「念九」は29日のこ とです。「房州」は今の千葉県です。千葉県には 「味形」という地名はありません，青洲の弟子が患 者の住所を台帳に記入する際に誤ったのです。そう いたしますと，「味」が間違っているか，あるいは 「形」が間違っているか, それとも「味」と「形」 の両者が誤っているかです．2つの字が間違ってい るよりも，1字だけが間違っている可能性がより大 きいことを念頭において地名を調べました。頭に 「味」のつく地名はありませんので, この字が誤つ 
ているはずです。そこで「○形」という地名を求め ました。すると館山市に「船形」という地名を見つ けました。この地名に間違いありません。次に患者 の実名はありませんが，「光林寺 室」となってお ります。「室」とは妻のことです。つまり「光林寺」 の住職の妻ということになります。当時住職が妻帯 できるのは浄土宗です。そこで館山市の「船形」地 区に浄土宗のお寺を求めますと, 唯一「西行寺」が ありました．幸いこのお寺には過去帳が残されてお り, 住職の栗山了空師には私の研究に好意を示して くださいました。この患者は 1817 年(文化 14 年) 6 月 に手術を受けたと思われますから，その後の 5 年間 について過去帳を精査しました。そうしますと， 1819 年(文政 2 年)の所に次のような法名を見つけま した。「文政二卯年二月壱十五日 明譽光林沙弥尼 中宿源之丞 妹」です。括々く青洲の弟子が患者 の名前を「光林沙弥尼」と聞いて,「光林寺」の住 職の妻と䛊解したと思われます。地名, 法名などか らこの人物と特定してまず間違いないと思います. この方は術後約 1 年 8 カ月生存したことになります. もう1例示しましょう。第 134 番目は「文政八年四 月念六日 南部槙田村 弥兵衛 妻」です。「乳嚴 姓名録」では住所の最初に「紀州」とか「房州」な どのように国名が記されております。そういたしま すと「南部」は津軽, 南部などの「南部」です。私 は現在の岩手県の地名について, 二万五千分の一の 地図や各種の地名辞典, 歴史地名辞典などで「槙田 村」を求めましたが，徒労に終わりました。「槙」 が誤っているのか, 「田」が間違っているのか, 数 年間検討しましたが，どうしてもわかりません。 あ らためて「乳嚴姓名録」を詳しく調べてみますと, 患者が紀州出身の場合, 国名が省略されて村の名前 から始まっていることに気がつきました，奧州の 「南部」は「なんぶ」ではなくて，紀州の「みなべ」 なのです. 現在の和歌山県日高郡南部町です.とこ ろが南部町には「槙田(村)」はありません。おそら く「槙田村」が誤っているのではないかと推定され
ます。「村」は決して間違えないと思います。そう すれば，「槙」か「田」のいずれかが䛊りであると 思われます。「槙」か「田」のいずれが誤りやすい かというと，「田」よりも「槙」です。「槙」も木偏 が間違っているか，旁の「真」が間違っているかの どちらかです。このような可能性を考慮しますと， 南部町に「埴田」(はねた)がありました。南部町に はほかに「田」のつく部落は「東吉田」のみで，こ の部落の可能性はまったくないといってもよいと思 います。埴田地区には昔からある寺は薬師寺だけで, この地区の人たちはほとんど同寺の檀徒です。住職 の畑崎周定師にお願いして過去帳を調査してもらつ たところ，1826年(文政 9 年)の条に次のような法名 が見つかりました。「文政九年十月二十七日 得号 名生信女 弥平 妻」です。「乳嚴治験録」の「弥 兵衛」と過去帳の「弥平」とは字が違っております が，発音は同じですから，両者は同一人物と見なし て差し支えないと考えられます。そうしますとこの 「弥平」の妻は術後約 1 年半生存したことになりま す。このような作業を 30 年以上も続けて，先ほど 申し上げましたように，合計 33 名の死亡年月日を 特定しました。術中死亡した例もありますし，最も 長い例では 42 年生存しております。果たしてこの 長期生存例が本当に癌であったか否かは, 今となっ てはわかりません。また 3 度目の手術の直後に死亡 した「尾州津島 松原定碩 妻」の例もあります. この例は青洲は再三手術を断ったのですが，是非に ということで手術し, 約 $1,000 \mathrm{~m} l$ の出血のため死亡 したようです。この例から青洲は腋窩の転移には手 をつけるなと教えております。

以上, 華岡青洲について, 私の研究の一端を申し 上げてまいりましたが，最後に華岡青洲から何を学 ぶかについてお話を申し上げて，私の講演を終わり たいと存じます。

現代の私たちからみますと, 青洲自ら著書を残さ なかったことが，大きな欠点と思われます。しかし これには青洲の確固たる理由がありました。青洲没 
後, 華岡塾「春林軒」に残された著書を整理した越 後の佐藤持敬は「華岡氏遺書目録序」において，生 前の青洲は常に「わが術は心に得て，手に応ずるも の. 口言う能わず，筆書く能わず.」と語ったと伝 えております。つまり青洲は, 患者一人一人皆異な るのであるから，それらを一つ一つ文章にすること は不可能であるとしたのです。もちろん青洲は治療 の原則を認めましたが，些細な点は皆異なるという ことを主張したのです。これは「個の医療」といっ てもよろしいかと思います。現代の治療はどうでし ょうか.「衆の医療」を行っております。言葉を換 えますと, 平均值の医療といっても過言ではありま せん、マニュアルの医療でもあります。医学教育の 任に当たっている人でもこのことをよく理解してい る人は少ないようであります。平均值の医療は多く の症例を対象にしたとき，初めて成り立つのです． 平均值の医療は, 目の前にいるある特定の患者に対 して，必ずしも成り立つとはかぎらないのでありま す。このことは西欧では「ステファヌスの予言」と して古くから知られております。現在 tailor made medicine, personalized medicineが喧伝されており ますが，これが「個の医療」であることは申すまで もないことは皆さんにもおわかりいただけると思い ます。このように青洲は個の医療を強く主張したた め，著書を書きませんでした。症例報告のような形 で残してくれたらよかったと思います。

青洲に対する大きな批判に, 彼が秘密主義を採つ たことが指摘されています。だから麻沸散による全 身麻酔が普及しなかったという非難です。果たして そうでしょうか. 麻沸散による全身麻酔は全国的に 普及しました。ただその事実がこれまで発掘されな かっただけであります。例えば津軽では 1864 年(元 治元年) 以前に藩医の三上道隆が鼻再接着術を行つ ていますし，福井藩の橋本左内が 1852 年(嘉永 5 年) から 1854 年(安政元年)にかけて全身麻酔下に乳癌の 手術などを行っていることがわかりました。さらに 九州の熊本では 1898 年(明治 31 年) 頃まで麻沸散に
よる全身麻酔が行われていました。これらの事実は いずれも私が発掘したものであります。

数年前, 私は杉田玄白の子供の杉田立卿が著した 「療乳嵓記」という本を入手しました。現在，日本 では唯一冊の写本です。これを読みますと, 立卿は 1813 年(文化 10 年) 9 月に江戸で全身麻酔下に乳癌の 手術を行っております。もちろん麻沸散による全身 麻酔です。立卿は青洲の門人ではありません。しか し青洲の弟子で，当時玄白の門に入っていた加賀 (金沢)の宮河順達から麻沸散の秘法を伝授されたも のでした。もちろん青洲は玄白の懇願によって，伝 授を許可したのであります。

では何故青洲は麻沸散の処方をみだりに他人に伝 授しない方針を採ったのでしょうか. 青洲は決して 心の狭い人間ではなかったと思います。麻沸散の処 方を知りたければ，いつでも入門しなさいと言って いろのです．青洲に少なくとも千数百人の弟子がい たことは，むしろ青洲の度量の大きさを示している ものでしょう。

情報が伝えられる際，一般的に正しく伝えられず， 少しずつ変容して伝えられます。麻沸散の処方が弟 子から弟子へと伝授されていく過程において，処方 内容ばかりでなく，それに伴う術後管理などの些細 な点が無視されて安全面がおろそかにされ，結果的 に致死的合併症を招くことを，青洲は最も恐れたの だと思われます。医療技術の安易な普及ほど恐ろし いことはありません。先程申し上げました東京慈恵 会医大青戸病院の例も典型的な例です。1948年頃, アメリカでは脊髄くも膜下麻酔で多くの死亡事故が 発生しました。早速事故の原因が究明されましたが, その結論は安易な普及にあると, 次のように述べら れています。

The factor most contributory to the tragic history is the ease with which it can be performed by anyone.

このことを指導者のみならず，医療に従事する方 は深く心に銘記すべきでありましょう。 
最後になりましたが，とくに若い方々に私から 3 つのお願いを申し上げたいと思います。第一は過去 を知ることです。単にかび臭い昔のことではありま せん．先輩たちの仕事を十二分に咀嚼することが過 去を知ることと思います。こうして初めて現在の自 分の立場と将来の方向性がわかるのです．第二は正 確なそして䛊解を招かないような記録を残すことで す。しっかりした論文を書くことです。経験だけで は，後輩に何も伝わりません。自分の正確な記録を
残してこそ，先輩たちの文献をも誤りなく読みこな すことができるのです。第三は必ず原文(オリジナ ル)を読むことです。引用には誤りが多いのです. 以上の 3 項目を守っていただければ，皆さんは大き な業績を上げることができると思います。

以上で本日の私の講演を終わりますが，さらに青 洲について詳しく知りたい方は，私の青洲に関する 著書「華岡青洲の新研究」,「華岡青洲と『乳嚴治験 録』」をご覧いただければ幸いに存じます。

The Mysterious Life of Seishu Hanaoka

- In Commemoration of the 200th Anniversary of the First General Anesthesia by Mafutsu-san-

\author{
Akitomo MATSUKI \\ Department of Anesthesiology, Hirosaki University School of Medicine
}

Seishu Hanaoka $(1760 \sim 1835)$ was a village physician of Kishu, currently Wakayama prefecture, and has been widely known as the first to perform the excision of breast cancer on a woman under general anesthesia by administrating his oral anesthetics "Mafutsu-san" in October of 1804.

As he did not write any medical books and detailed records on his family himself, many things associated with him, his family and the developing process of "Mafutsu-san" remain unknown to us. For example, the name and age of his youngest daughter has never been clarified.

The author repeated animal experiments using "Mafutsu-san" the same as Seishu did, to understand the process of "Mafutsu-san" development.

Furthermore, the author found the necrology of Jizo-ji temple, formerly Hanaoka's family temple, to add new information about his family tree. The thoughts of Seishu Hanaoka on medicine, such as internal medicine and surgery should not be specialized but should be united, and patients should be treated as living bodies and as a whole, considering their pathophysiology, can be accepted as true even in our day.

Key Words : Seishu Hanaoka, Mafutsu-san, General anesthesia 